\title{
Fluid Inclusion Investigations of the Masjed Daghi Copper-Gold Porphyry-Epithermal Mineralization, East Azerbaijan Province, NW Iran
}

\author{
Solat Atalou', Nima Nazafati' ${ }^{1}$, Mohammad Lotfi², Mehraj Aghazadeh ${ }^{3}$ \\ ${ }^{1}$ Department of Geology, Science and Research Branch, Islamic Azad University, Tehran, Iran \\ ${ }^{2}$ Department of Geology, North Tehran Branch, Islamic Azad University, Tehran, Iran \\ ${ }^{3}$ Department of Geology, Payame Nour University, Tehran, Iran \\ Email: atasolat@yahoo.com
}

How to cite this paper: Atalou, S., Nazafati, N., Lotfi, M. and Aghazadeh, M. (2017) Fluid Inclusion Investigations of the Masjed Daghi Copper-Gold PorphyryEpithermal Mineralization, East Azerbaijan Province, NW Iran. Open Journal of Geology, 7, 1110-1127.

https://doi.org/10.4236/ojg.2017.78074

Received: February 15, 2016

Accepted: August 12, 2017

Published: August 15, 2017

Copyright (c) 2017 by authors and Scientific Research Publishing Inc. This work is licensed under the Creative Commons Attribution International License (CC BY 4.0).

http://creativecommons.org/licenses/by/4.0/

(c) (i) Open Access

\begin{abstract}
The Masjed Daghi mineralization is located $30 \mathrm{~km}$ southeast of Jolfa city at the bank of Araxes River, northwest Iran. This area is situated in the AlborzAzarbaijan structural zone of Iran. The most widespread rocks in the mineralization area are andesite and trachyandesite, while there are rock units of latite tuff, andesitic agglomerate, and hornblende porphyry basalt in eastern hills and Eocene flysch in the southern part of the area. Several intrusive bodies are present in the study area, from which the dominant intrusive rock hosting the mineralization is diorite porphyry. The mineralized rock units of the area are cut by different diorite ad mafic dikes. The most prevalent texture of mineralization is dissemination, while open space filling textures including veins and veinlets, are common as well. Diverse types of alteration including potassic, phyllic, argillic, silicification, and a little of carbonatization were recognized in the field and microscopic observations as well as by XRD. In addition to thick silica veins and stockwork zones, some silica, barite, sulfide, and calcite veins and veinlets have occurred in the Masjed Daghi mineralization area. In this research, 26 doubly polished thin sections (wafers) were prepared and investigated. Four samples were taken from surface veins, while 22 samples were chosen from core samples (of 6 boreholes) of white and greywhite silica, and silica-barite veins. The fluid inclusion studies on 105 primary fluid inclusions indicated five phases for inclusions including: 1) liquid or gas, 2) liquid and gas, 3) liquid, gas, and solid, 4) liquid, gas, halite, and solid, and 5) liquid, gas, halite, and two types of solids. The data gained from fluid inclusions approved two mineralization fluids which caused porphyry and epi-
\end{abstract}


thermal mineralizations. The porphyry fluid inclusions were homogenized in temperatures of $122^{\circ} \mathrm{C}$ to $550^{\circ} \mathrm{C}$ with a maximum of $700^{\circ} \mathrm{C}$ and average salinity of $55 \mathrm{wt} \% \mathrm{NaCl}$ equivalent, while the epithermal inclusions indicated an average homogenization temperature of $186^{\circ} \mathrm{C}$ with an average salinity of 6.23 wt\% $\mathrm{NaCl}$ equivalent.

\section{Keywords}

Fluid Inclusion, Porphyry Mineralization, Epithermal, Alteration, Diorite, Masjed Daghi, Siyah Roud

\section{Introduction}

The Masjed Daghi mineralization, with general coordinates of $38^{\circ} 52^{\prime} 40^{\prime \prime} \mathrm{N}$ and $45^{\circ} 56^{\prime} 25^{\prime \prime} \mathrm{E}$, is located $30 \mathrm{~km}$ southeast of Jolfa city at the bank of Araxes River, northwest Iran. The exploration of Masjed Daghi mineralization area was commenced in 2000 by the Geological Survey of Iran (GSI) by means of preparation of 1:3000 and 1:5000 geologic maps, rock sampling, and digging 18 exploration boreholes [1]. By recognizing some gold-copper anomalies, the exploration was continued with the digging of 16 exploration boreholes with the total length of 1882 meters [2]. So far some PhD and MSc theses as well as some individual investigations were performed on the Masjed Daghi mineralization [3] [4] [5] [6], but some crucial questions about the genesis of the fluids causing the mineralization remained open. Recent exploration by the National Iranian Copper Industries Company with 67 boreholes with the total length of 38,600 meters estimated 204 million tons of copper $0.3 \%$ and $20 \%$ million tons of gold $320 \mathrm{ppb}$ [2]. The age of porphyry mineralization of Masjed Daghi using Re-Os method on molybdenite present in silica stock works is $20.46+3.55$ million years [7]

The fluid inclusion studies performed in this study revealed valuable data about the characteristics of the mineralization including temperature of the formation of minerals, the pressure dominating the environment during the mineralization, the fluid density forming the minerals, the source and chemical composition of mineralizing fluids, the occurrence of boiling in the course of mineralization, depth, and type of mineralization. There is little attention given to research on the mentioned topic, especially in Iran, which is the main reason to carry out this research; therefore, the present study tries to investigate fluid inclusion of the Masjed Daghi Copper-Gold Porphyry-Epithermal Mineralization, East Azerbaijan Province, NW Iran.

\section{Materials and Methods}

This research was performed in four main stages which include: 1) Field observations and sampling, 2) Sample preparation and making 26 doubly polished thin sections, 3) Petrography of the sections, and 4) Geothermobarometric studies and Raman laser spectroscopy measurements. From 26 doubly polished thin 
sections (wafers) four samples were taken from surface veins, while 22 samples were chosen from core samples (of 6 boreholes: No. 38, No. 39, No. 45, No. 49, No. 52, and No. 66) of different types of mineralized silica veins (Figure 1). The fluid inclusion studies on 105 primary fluid inclusions (50 multi-phase and 55 two-phase fluid inclusions) were conducted in the Iranian Mineral Processing Research Center (IMPRC) using a THMS600 heating-freezing Linkam stage installed on a ZEISS microscope with the thermal range between $-196^{\circ} \mathrm{C}$ and $+600^{\circ} \mathrm{C}$. In order to recognize dubious minerals within fluid inclusions, 10 fluid inclusions were analyzed using Raman laser spectroscopy in the physics laboratory at the Tarbiat Modarres University of Tehran.

\section{Geology and Mineralization of the Study Area}

The Masjed Daghi area is located within the Alborz-Azerbaijan structural subdivision of Iran [8]. Andesite and trachy-andesite are the most abundant rock units of the study area and demonstrate a porphyritic texture including phenocrysts of plagioclase, amphibole, and biotite. There are rock units of latite tuff,

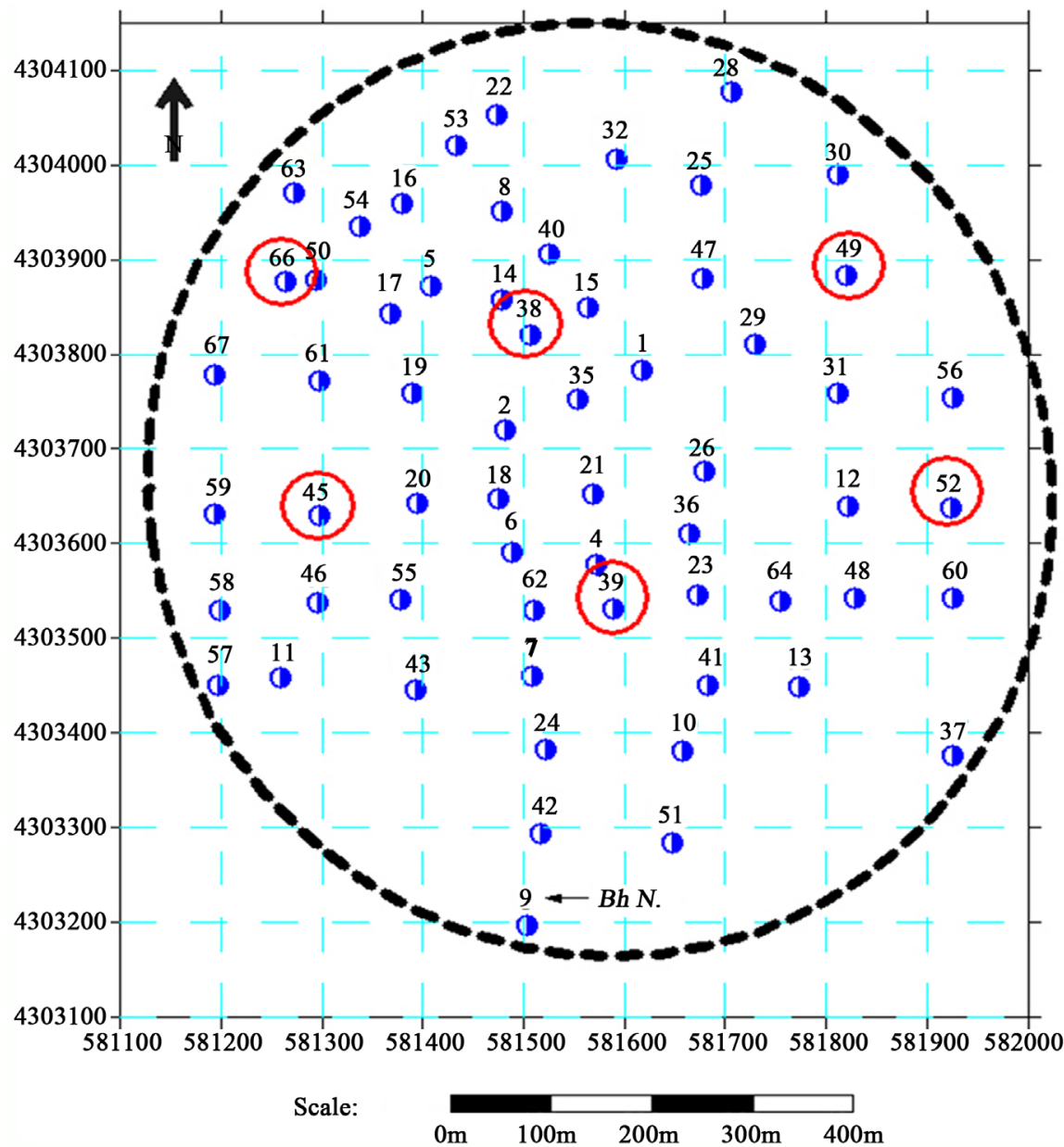

Figure 1. Location and number of boreholes in the study area. The sampled boreholes have been marked with a red circle. 
andesitic agglomerate, and hornblende porphyry basalt in eastern hills as well as Eocene flysch in the southern part of the area. The most important plutonic rocks in the region that host most of copper, gold, and molybdenum mineralizations at the both banks of Araxes River belong to the intrusive rocks of Gharadagh. Unlike most of the known porphyry deposits of Iran which are situated in the Urmia-Dokhtar zone, the northwestern ore deposits of Iran are located in the Alborz-Pontides zone that continue to northeast of Turkey, and Lesser Caucasus [9]. The porphyry and epithermal deposits of Agarat, Paraghachai, and Kajaran in Armenia [10] as well as the porphyry depsoits of Sungun, Haftcheshmeh, Ali Javad, Anjerd, Sonajil, Masjed Daghi, Niaz, and Saheb Divan in Iran [11] are examples of this type of mineralization. The major intrusive body hosting the mineralization in Masjed Daghi is diorite, where most of the boreholes were dug. Nevertheless, several types of other intrusive rocks are present in the study area which include quartzmonzonite in the center (from the depth of 740 to $1012 \mathrm{~m}$ of the borehole No. 39, from the depth of 30 to $806 \mathrm{~m}$ of the borehole No. 35, and from the depth of $84 \mathrm{~m}$ of the borehole No. 2), monzodiorite (from the depth of 590 to $740 \mathrm{~m}$ of borehole No. 40), and quartzdiorite (from the depth of 740 to $798 \mathrm{~m}$ of borehole No. 40, and from the depth of 424 to $486 \mathrm{~m}$ of borehole No. 49) in the north. Granodiorite can be observed in the southeast of the mineralization area (from the depth of 591 to $614 \mathrm{~m}$ of borehole No. 37), while amphibole diorite is present on the surface of the area. All the intrusive rocks of the study area demonstrate a porphyritic texture.

Alteration at Masjed Daghi is pervasive and includes potassic, phyllic, argillic, silicification, alunitic, and a little of carbonatization which were recognized using microscopic and XRD studies. Potassic alteration can be observed in eastern and western edges of the seasonal river called Arpachaei. Phyllic alteration is present as a halo around the potassic alteration. These two alterations continue to a depth of $1011 \mathrm{~m}$. Argillic and advanced argillic alterations are widespread in the mineralization area and gradually convert into propylitic alteration to the east. Silicification has affected most of the rock units in the area, while chlorite alteration is present in andesite to latite dikes. Chalcopyrite, molybdenite, bornite, galena, chalcocite, covellite, sphalerite, magnetite, hematite, arsenopyrite,pyrite, and sulfosaltes of tetrahedrite and tennantite are the most abundant ore minerals in the samples taken from the boreholes. Hematite, goethite, magnetite, and pyrite are the minerals present in surface samples. Dissemination and open space filling textures including veins, and veinlets are the most abundant forms of mineralization in the area. The rock units of the mineralization area are cut by several diorite and mafic dikes that often have been intruded along the faultes. Diorite dikes have a similar chemical and mineralogical composition with the andesitic rocks. Mafic dikes show a basaltic composition and differ in composition from the other rocks in the area. They lack quartz, while are enriched in $\mathrm{Ni}$ and $\mathrm{Mg}$ [2].

Based on microscopic and macroscopic studies, in addition to mineralized 
thick silica veins and silica stockwork zones, the presence of mineralized veins of grey silica, white silica, silica-barite, sulfide, gypsum, and calcite at Masjed Daghi is of interest. Silica stockwork veinlets are grey in color and based on microscopic studies (in samples like BH 24-436 and BH8-318) contain disseminated or open space filling pyrite, chalcopyrite, molybdenite, bornite, and Chalcocite (Figure 2(a)). These veins are cut by rich sulfide veins. Grey silica veins demonstrate a halo of alkali-feldspars and contain disseminated ore minerals like bornite, chalcopyrite, Chalcocite, covellite, molybdenite, sphalerite, magnetite, and hematite (in samples from BH8-639, BH52-817, BH36-622, and BH49-801) (Figure 2(b)). The grey mineralized veins which are cut by white silica veins are

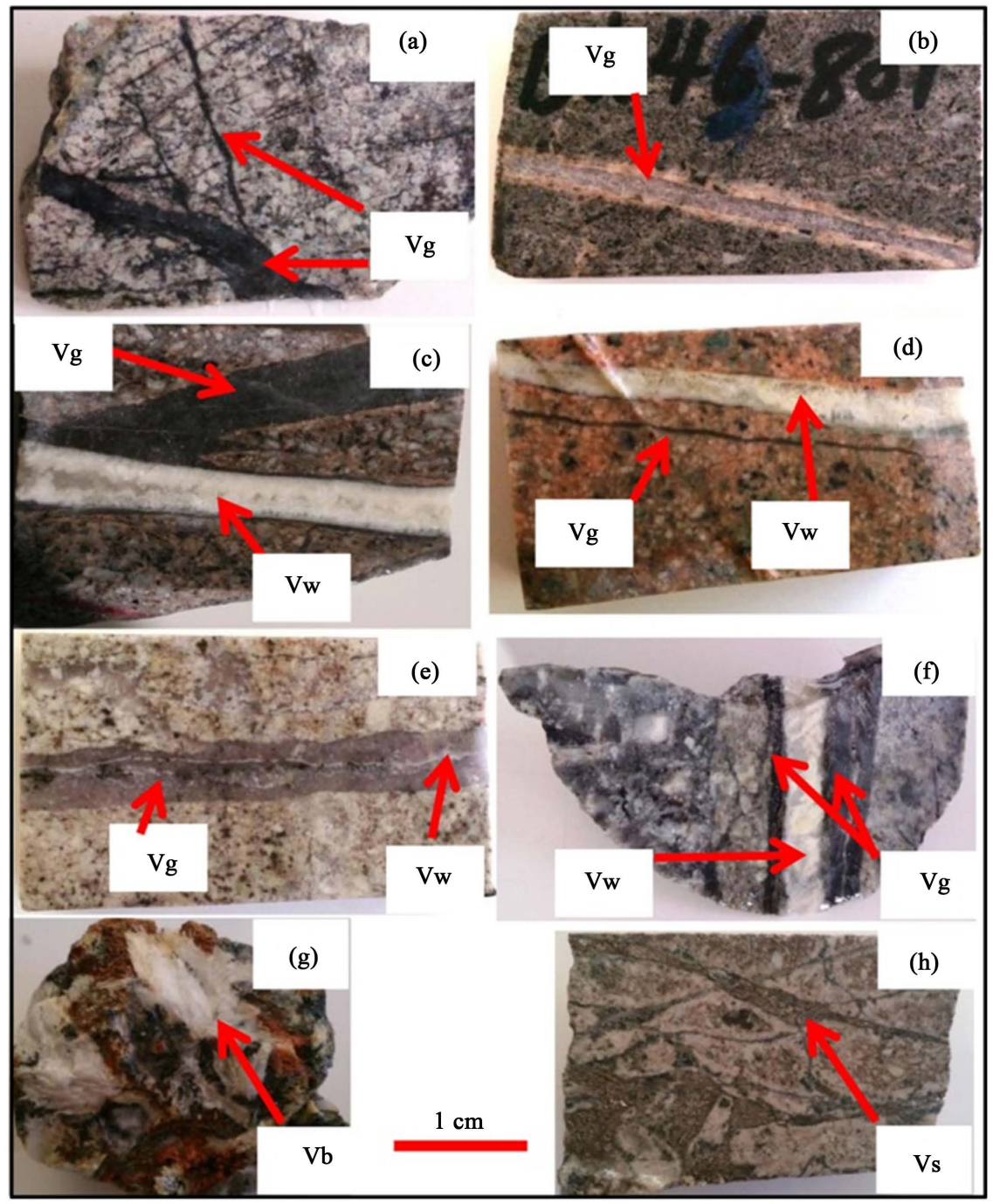

Figure 2. The image of some samples taken from the boreholes to study fluid inclusions. (a) Grey silica stockwork veinlets (vg) in sample BH8-318; (b) Grey silica veinlets (vg) with alkali-feldspar halo in sample BH49-801; (c) Grey veinlets (vg) cut by white silica veins (vw) in sample BH39-387; (d) White silica vein (vw) parallel with grey vein (vg) in sample BH66-466. ((e), (f)) White silica veinlets (vw) filling the open spaces of grey silica veins (vg) in samples BH49-605 and BH45-353; (g) Barite-silica veins (vb) in sample BH39-199. (h) Rich sulfide veinlet (vs) in sample BH9-655. 
in average $3 \mathrm{~mm}$ thick (samples from BH39-383 and BH39-601) and hosted by diorite. White silica veins (sample BH52-414, BH45-369, BH49-605a, and BH45831 ) are the youngest veins in the area and often lack mineralization. In a few cases, they contain pyrite, chalcopyrite, and galena (e.g. sample from BH45-831) and tetrahedrite and tennantite (sample BH39-727). These veins with a different thickness ranging from $2 \mathrm{~mm}$ to $1 \mathrm{~cm}$ are observed in three forms compared to grey silica veins; 1) intersecting the previously formed veins (sample $\mathrm{BH} 39-387$ ) (Figure 2(c)), 2) parallel to the previously formed veins (BH66-466) (Figure $2(d)), 3$ ) filling the open spaces of grey silica veins (samples BH49-605 and sample BH45-353) (Figure 2(c) and Figure 2(f)).

Barite-silica veins are observed in samples close to the surface (e.g. sample BH39-199) and have cut rich sulfide and grey sulfide veins (Figure 2(g)). Often the silica veins along with barite have a thickness of $1 \mathrm{~mm}$ to $5 \mathrm{~cm}$. Sulfide veins with a thickness of $0.2 \mathrm{~mm}$ to $1.5 \mathrm{~mm}$ are rich in pyrite and chalcopyrite. Sulfide veins intersect grey silica veins or intrude into these veins and are cut by white silica veins. Some of sulfide veins are formed from pyrite (sample BH42-296), chalcopyrite (sample BH39-601), or pyrite and chalcopyrite (sample BH9-655) (Figure 2(h)). Gypsum veins are hosted by diorite and cut grey silicate veins or are formed within them. These veins are less frequent compared to other veins in samples like BH39-404 and BH39-632 with a thickness of $2 \mathrm{~cm}$ and lack mineralization. Calcitic veins are the rarest vein type in the deposit. The silicacarbonate veins with calcite content of $45 \%$ to $50 \%$ and quartz content of $40 \%$ to $50 \%$ contain euhedral pyrite with sieve texture along with galena. In sample $\mathrm{BH} 45-353$, two generations of quartz were recognized; 1) large quartz crystals $(0.1$ to $0.5 \mathrm{~mm})$ which were formed along with calcites of the same size and 2) small quartz crystals which are in the form of white veinlets within grey silica veins. The overall trend of geologic structures (dikes, silica veins, and stockworks) is east-west and therefore compatible with the general trend of the main faults. Some north-south trending normal faults have cut and shifted the main faults and veins, among which the most important one is Arpachaei fault that has had an important role in the mineralization of Masjed Daghi and has displaced silica veins and potassic zone of the west of Arpachaei about 100 meters towards the south.

\section{Fluid Inclusions Studies of the Masjed Daghi Deposit}

In order to study the 105 primary fluid inclusions in the samples, the following characteristics of the inclusions were considered and investigated (Sections 4-1, to $4-13)$.

\subsection{Primary and Secondary Inclusions}

One of the most principal works in petrography stage is to recognize the primary inclusions as the best sources for investigation from other inclusions. Since we cannot use secondary fluid inclusions and those that have necking down to rec- 
ognize the physico-chemical conditions of mineralizing fluids, in the present study we have disregarded the secondary and pseudo-secondary inclusions.

\subsection{Forms of Fluid Inclusions}

Based on the petrographic studies, the multi-phase fluid inclusions of Masjed Daghi include: irregular polyhedrons (sample BH49-801), regular polyhedrons (sample BH52-817) and negative crystals (samples BH49-605, BH66-466, BH52817, and BH39-1011). Two-phase fluid inclusions are rich in liquids and singlephase liquids consist of bar forms (sample BH45-831), shapeless (sample BH49605a, BH45-831), elongated (sample BH49-605a, BH39-199, BH52-414), regular polyhedron (sample BH39-199, BH52-414, BH52-817), and negative crystals (sample BH39-199, BH52-414). The phenomenon of necking down is observed in sample BH49-605a with occasional primary inclusions of shapeless, twophased, and elongated forms.

\subsection{Solid phases of Fluid Inclusions}

In multi-phase fluid inclusions of Masjed Daghi, the dominating solid phase is halite with surface morphological features (cubic form). Sylvite is smaller than halite and is dissolved in a lower temperature than halite. The opaque solid phase is hematite in two major forms; 1) hexagonal which is red in color or 2) masses in the dark red to brown color. In some cases, two solid phases were recognized in the inclusions. These were recognized-using Raman laser spectroscopy-to be rutile, magnetite, arcanite, cerussite, anhydrite, asphalerite, and anglesite.

\subsection{The Classification of Fluid Inclusion Phases of Masjed Daghi}

The fluid inclusions of Masjed Daghi deposit can be divided into three major phases which are described in the following:

A) Single-phase fluid inclusions

The Liquid (L) and gas (V) single phase fluid inclusions of Masjed Daghi are of two types that are described as follows:

a) Liquid single-phase (L): In barite vein of sample BH39-199 and white silica veins of samples BH52-414 and BH45-831 the primary single-phase liquid inclusions are frequent and are present along with primary two-phase inclusions enriched in liquid. These inclusions are observed in the forms of elongated, regular polygonal, negative crystal, bar, and shapeless with 5 to 18 micrometers size and the salinity of 0.21 to $9.41 \mathrm{wt} \% \mathrm{NaCl}$ equivalent.

b) Gas single-phase (V): The single-phase gas fluid inclusions are abundant in white silica veins of samples BH49-605, BH39-1011, and BH66-466. In grey silica veins, they are present along with two-phase and lots of multi-phase fluid inclusions.

B) Two-phase liquid and gas fluid inclusions that are two types:

a) Two-phase liquid and gas, rich in liquid $(\mathrm{L}+\mathrm{V})$ : The most abundant fluid 
inclusions of Masjed Daghi with 52 cases belong to this type. This type is present at the depth of 199 to 831 meters in most of the samples. The size of the fluid inclusions varies between 5 and 18 micrometers with the average size of 9.8 micrometer. The average homogenization temperature is $186^{\circ} \mathrm{C}$ with a maximum of $289^{\circ} \mathrm{C}$. The maximum salinity is $9.41 \mathrm{wt} \% \mathrm{NaCl}$ equivalent with an average of 6.23 . The average density is calculated to be $0.92 \mathrm{~g} / \mathrm{cm}^{3}$ and the ice melting temperature is $-3.8^{\circ} \mathrm{C}$ in average with a maximum of $-6^{\circ} \mathrm{C}$. The average eutectic temperature is $-40.8^{\circ} \mathrm{C}$ with a maximum of $-47^{\circ} \mathrm{C}$. The samples were taken from the veins in the potassic and phyllic alteration zones of diorite. In two-phase fluid inclusions rich of liquid more than $70 \%$ of the volume of the inclusion is filled with liquid. In white silica veins of samples BH45-369, BH49-605a, BH45-831, BH52-414, and BH39-199 the primary two-phase inclusions are also rich in liquid.

b) Two-phase liquid and gas, rich in gas $(\mathrm{V}+\mathrm{L})$ : In this type of inclusions observed in white silica veins (in potassic alteration of diorite; samples BH49-801 and $\mathrm{BH} 66-466$ ), about $85 \%$ to $95 \%$ of the inclusion is filled with gas, while $5 \%$ to $15 \%$ of it is occupied by liquid phase. The homogenization temperature of two-phase inclusion $(\mathrm{V}+\mathrm{L}-\mathrm{V})$ to gas phase is $416^{\circ} \mathrm{C}$. Grey silica veins of these samples have lots of multi-phase fluid inclusions.

C) Multi-phase liquid, gas, and solid $(\mathrm{L}+\mathrm{V}+\mathrm{Ha}+\mathrm{S} 1+\mathrm{S} 2)$ fluid inclusions

The multi-phase inclusions can be divided into three major groups based on their contents which can be liquid, gas, and solid $(\mathrm{L}+\mathrm{V}+\mathrm{Ha}+\mathrm{S} 1+\mathrm{S} 2)$ containing 3, 4, or 5 phases.

a) Three-phase inclusions of liquid, gas, and solid (LVS) including 4 types of i) liquid, gas, halite $(\mathrm{L}+\mathrm{V}+\mathrm{Ha})$, ii) liquid, gas, hematite $(\mathrm{L}+\mathrm{V}+\mathrm{S}$ (Hematite)), iii) liquid, gas, solid1 ( $\mathrm{L}+\mathrm{V}+\mathrm{S} 1)$, and iv) gas, liquid, solid2 $(\mathrm{V}+\mathrm{L}+\mathrm{S} 2)$.

b) Four-phase inclusions of liquid, gas, halite, and solid (LVHaS) including 3 types of i) liquid, gas, halite, sylvite $(\mathrm{L}+\mathrm{V}+\mathrm{Ha}+\mathrm{Sy})$, ii) liquid, gas, halite, hematite ( $\mathrm{L}+\mathrm{V}+\mathrm{Ha}+\mathrm{S}($ Hematite) $)$, and iii) liquid, gas, halite, solid $(\mathrm{L}+\mathrm{V}+\mathrm{Ha}$ $+\mathrm{S})$.

c) Five-phase inclusions of liquid, gas, halite, solid1, solid2 (LVHaS1S2) including 4 types of i) liquid, gas, halite, sylvite, hematite $(\mathrm{L}+\mathrm{V}+\mathrm{Ha}+\mathrm{Sy}+\mathrm{S}$ (Hematite)), ii) liquid, gas, halite, hematite, solid? ( $\mathrm{L}+\mathrm{V}+\mathrm{Ha}+\mathrm{S}$ (Hematite) + $\mathrm{S}$ ?), iii) liquid, gas, halite, sylvite, solid? ( $\mathrm{L}+\mathrm{V}+\mathrm{Ha}+\mathrm{Sy}+\mathrm{S}$ ?), and iv) liquid, gas, halite, Solid1?, solid2? (L + V + Ha + S1 + S2).

The number of multi-phase fluid inclusions has been 52 and the highest number was allocated to 4-phases and the least ones were allocated to 5-phases. The average homogenization temperature of multi-phase inclusions was $343^{\circ} \mathrm{C}$, while the maximum temperature was $550^{\circ} \mathrm{C}$. The average homogenization temperature of halite was $465^{\circ} \mathrm{C}$ with a maximum of $550^{\circ} \mathrm{C}$. The average salinity was $55 \mathrm{wt} \% \mathrm{NaCl}$ equivalent with a maximum of 66.9. The average homogenization temperature of sylvite-which was mostly observed in five-multi-phase inclusions-, was $407^{\circ} \mathrm{C}$ with an average salinity of $31.13 \mathrm{wt} \% \mathrm{KC} 1$ equivalent. Most of the multi-phase inclusions of liquid, gas, and solid were present in the grey silica 
veins located in the potassic alteration zone of diorite (samples BH49-605, BH66-466, BH39-1011, BH49-801, BH52-817, and BH38-441). Only a few twophase and single-phase gas fluid inclusions can be observed in white silica veins of these samples. In most fluid inclusions, the dissolution temperature of salt phase is higher than the homogenization temperature of the vapor phase (Thsalt $>$ Th1-v). The grey silica veins with multi-phase fluid inclusions are indicators of porphyry mineralization conditions, while the single- and two-phase inclusions in white silica and barite veinlets indicate the epithermal mineralization conditions.

\subsection{Changing the Characteristics of Fluid Inclusions by Increasing Depth and in Northern and Southern Parts of the Mineralization Zone}

The overall changes of 104 fluid inclusions of 6 boreholes from five depth levels of $199,414,605,817$, and 1011 meters were investigated (Table 1). By increasing the depth, the maximum size, the number of two-phase fluid inclusions, the dissolution temperature of halite, and the ice melting temperature of fluid inclusions were reduced regularly, while the number of multi-phase inclusions, homogenization temperature, and the salinity and density of fluid inclusions were increased regularly. The study of features of fluid inclusions in the boreholes No. 49, No. 38, and No. 66 in northern part and boreholes No. 52, No. 39, No. 45 in southern part of the study area demonstrate that the diversity of phases of fluid inclusions, the average homogenization temperature, the salinity, the salts dissolution temperature, the ice melting temperature, and the presence of solid hematite and sylvite phases in northern part of the area were increased considerably compared to the southern part and therefore the function of mineralizing fluids in northern part has been stronger.

\subsection{The Correction and Determination of the Pressure and Depth of Mineralization}

Despite homogenization of some fluid inclusions into gas, some inclusions of samples BH49-605a, BH45-831, BH39-199, and BH52-414 were homogenized into liquid phase. Therefore, in order to know the real temperature of trapping we need to revise and correct the pressure. In this regard, the calculations of

Table 1. Changes in characteristics of fluid inclusions with depth increase. The porphyrymineralization features increase with depth.

\begin{tabular}{|c|c|c|c|c|c|c|c|c|c|c|}
\hline $\begin{array}{l}\text { Depth } \\
\text { sample }\end{array}$ & BHNO. & Number FI. & Max siz & $\mathrm{L}+\mathrm{V}$ & $\mathrm{L}+\mathrm{V}+\mathrm{Ha}+\mathrm{Sy}+\mathrm{Hem}$ & Homo ${ }^{\circ} \mathrm{C}$ & Halite Sol. ${ }^{\circ} \mathrm{C}$ & Salinity & Density & Ice melt ${ }^{\circ} \mathrm{C}$ \\
\hline $199 \mathrm{~m}$ & 39 & 13 & 18 & $100 \%$ & $0 \%$ & 174 & - & 5.69 & 0.93 & -3.45 \\
\hline $414 \mathrm{~m}$ & $52-45-66-38$ & 21 & 16 & $66.7 \%$ & $33.3 \%$ & 235 & 504 & 21.5 & 1.04 & -3.03 \\
\hline $605 \mathrm{~m}$ & 49 & 27 & 16 & $48.2 \%$ & $51.8 \%$ & 271 & 442 & 26 & 1.04 & -3.63 \\
\hline $817 \mathrm{~m}$ & $45-49-52$ & 34 & 15 & $35.3 \%$ & $64.7 \%$ & 310 & 487 & 41.3 & 1.15 & -5.43 \\
\hline $1011 \mathrm{~m}$ & 39 & 9 & 12 & $0 \%$ & $100 \%$ & 287 & 428 & 49.7 & 1.24 & - \\
\hline
\end{tabular}


pressure correction of fluid inclusion in sample BH39-1011 (having only $\mathrm{NaCl}$ and homogenized to liquid phase under predetermined salinity and homogenization temperature) is presented as an instance. To calculate the depth of trapping of the fluid inclusions of Masjed Daghi the Haas diagram was used [12]. In this regard, the trapping depth of an inclusion showing $7.36 \mathrm{wt} \% \mathrm{NaCl}$ equivalent and $289^{\circ} \mathrm{C}$ homogenization temperature was $813 \mathrm{~m}$. The pressure of trapping of this inclusion was calculated to be 215 bar, while its density was 0.8 $\mathrm{g} / \mathrm{cm}^{3}$ based on the Wilkinson's diagram [13]. The calculated pressure was corrected using Shepherd's (1985) pressure-temperature diagrams which revealed a trapping temperature of $315^{\circ} \mathrm{C}$ with a $26^{\circ} \mathrm{C}$ correction value.

In order to calculate the pressure and the depth of mineralization, the Gunter's diagram [13] was used, a diagram that is appropriate for inclusions with 30 to $80 \mathrm{wt} \% \mathrm{NaCl}$ equivalent. The results were in a good agreement with the data obtained from Flincor software [14]. The fluid inclusion studies on Masjed Daghi samples indicated that the inclusions with $\mathrm{Th}($ halite $)>\mathrm{Th}(\mathrm{L}-\mathrm{V})$ are the most abundant ones and therefore the A curve which gives a better estimate of trapping pressure (compared to B and C curves) was utilized. Based on the Th(L-V) data, the average homogenization temperature and salinity after pressure correction were $380^{\circ} \mathrm{C}$ and $55 \mathrm{wt} \% \mathrm{NaCl}$ equivalent, respectively. These could be, nevertheless, increased to $401^{\circ} \mathrm{C}$ and $71 \mathrm{wt} \% \mathrm{NaCl}$ equivalent. In this respect, the trapping pressure of inclusions and the depth of mineralization have been calculated to be 1150 bar and $4.34 \mathrm{~km}$, respectively.

\subsection{The Solidification of Fluid Inclusions}

The study of solidification (freezing temperature) of fluid inclusions is considered as the best method to study the salinity of fluids because the freezing point of water is related to the amount and type of salt dissolved in the fluid. By using ice melting diagram the amount and type of salt can be calculated [15]. By recognizing the temperature of the first freezing stage or the last ice melting point we can understand the dissolution amount of each salt type in water [15]. One of the most important methods to identify the fluid composition is to use eutectic temperature or primary melting temperature that can show a schematic representation of the composition of cations and anions present in the fluid [16]. Ice melting point of 53 fluid inclusions in Masjed Daghi is between $-0.3^{\circ} \mathrm{C}$ and $-6^{\circ} \mathrm{C}$ with an average of $-3.83^{\circ} \mathrm{C}$. The eutectic temperature in seven fluid inclusions in Masjed Daghi is equal to $-30^{\circ} \mathrm{C}$ to $-47^{\circ} \mathrm{C}$ with an average of $-40.86^{\circ} \mathrm{C}$. Regarding the eutectic temperatures of $-20.8^{\circ} \mathrm{C}$ and $-10.6^{\circ} \mathrm{C}$, respectively for $\mathrm{H}_{2} \mathrm{O}-\mathrm{NaCl}$ and $\mathrm{H}_{2} \mathrm{O}-\mathrm{KCI}$, the presence of salts other than halite and sylvite in the fluids was necessary, in order to reduce the eutectic temperature to $-47^{\circ} \mathrm{C}$. Based on the measured eutectic temperatures, compositions such as $\mathrm{H}_{2} \mathrm{O}-\mathrm{CaCl}_{2}, \mathrm{H}_{2} \mathrm{O}$ $\mathrm{Na}_{2} \mathrm{CO}_{3}-\mathrm{K}_{2} \mathrm{CO}_{3}, \mathrm{H}_{2} \mathrm{O}-\mathrm{NaCl}-\mathrm{FeCl}_{2}, \mathrm{H}_{2} \mathrm{O}-\mathrm{FeCl}_{2}, \mathrm{H}_{2} \mathrm{O}-\mathrm{NaCl}-\mathrm{MgCl}_{2}, \mathrm{H}_{2} \mathrm{O}-\mathrm{MgCl}_{2}$, $\mathrm{H}_{2} \mathrm{O}-\mathrm{NaCl}-\mathrm{KCl}$ would be the most appropriate predictable salt compositions in fluid inclusions of Masjed Daghi according to Boriswnko (1977) (cited in [17]). 


\subsection{Chloride and Sulfide Complexes}

Understanding the compositions of fluids is an important step to recognize the ligands carrying metals [17]. Many researchers support the presence of ligands such as $\mathrm{HS}-$ or $\mathrm{H}_{2} \mathrm{~S}, \mathrm{CL}-$, and $\mathrm{OH}-$ to transfer metals in the form of complex ions. To understand the ore genesis and the transfer medium of elementes like $\mathrm{Cu}, \mathrm{Fe}$, and Mo based on the fluid inclusion studies, the diagram presented by Large [18] was used. Plotting the fluid inclusion data of the studied samples on this diagram demonstrated two chloride and sulfide complex areas for different types of mineralization. Most of the 47 samples of multi-phase fluid inclusions related to grey veins of Masjed Daghi are situated in the chloride ligand and copper-gold porphyry areas, where the $\mathrm{Cl}$-anion is the dominant ligand for carrying copper, iron, and molybdenum and chloride salts have caused the reduction of eutectic temperature to $-47^{\circ} \mathrm{C}$. A few of multi-phase fluid inclusions and the entire two-phase fluid inclusions of white silica and barite veins are situated in the realm of sulfide complex ligand (Figure 3). Akbarpour believes that probably the sulfide complexes were responsible for carrying epithermal gold which was precipitated along with silica and barite in the veines and stockwork zones [3].

The sylvite-bearing inclusions of Masjed Daghi demonstrate an average wt\% $\mathrm{NaCl}$ equivalent of 44.57 , while an average of $31.13 \mathrm{wt} \% \mathrm{KCl}$ equivalent. The Characteristics of the Masjed Daghi fluid inclusions were compared to eight

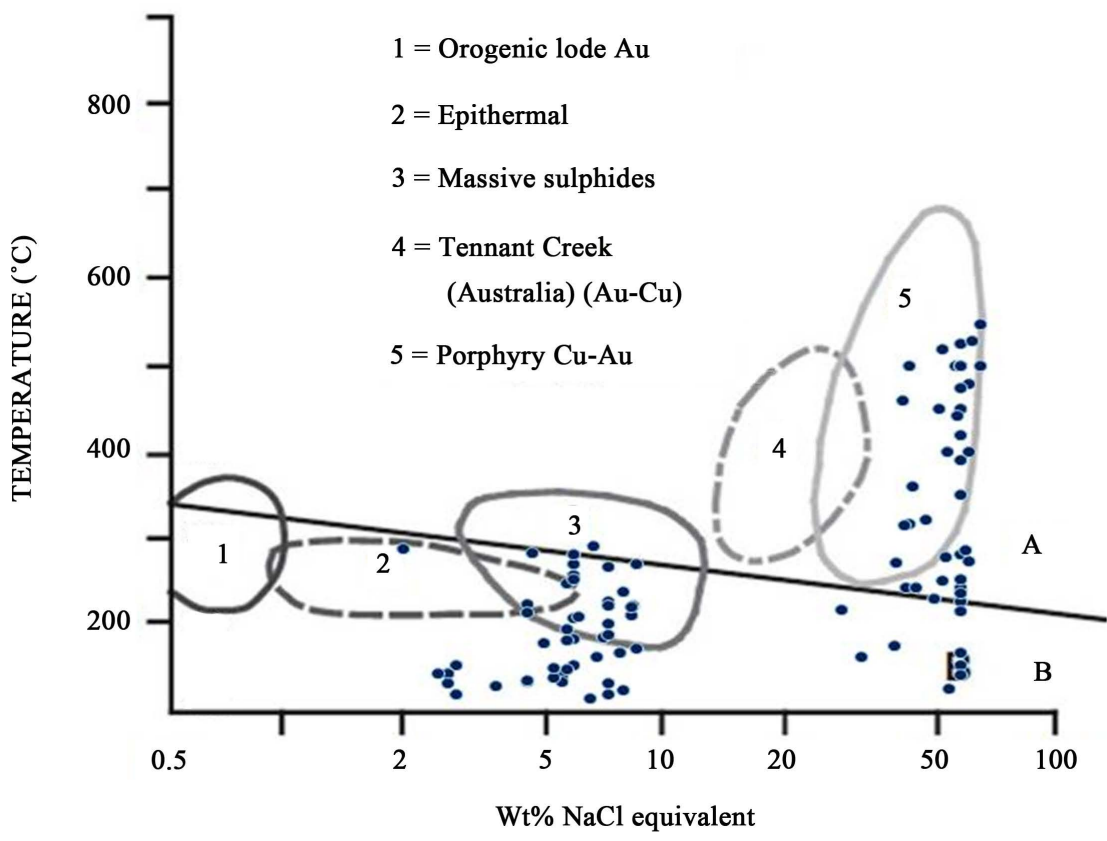

\section{A: FIELD OF DOMINANT CHLORIDE COMPLEXING \\ B: FIELD OF DOMINANT SULPHIDE COMPLEXING}

Figure 3. Grey silica vein samples mostly fall within chloride ligand and $\mathrm{Cu}-\mathrm{Au}$ porphyry deposits area (area A) of the diagram presented by Large (1988) [18], while the samples of white silica veins fall within the sulfide ligand area (area B) of epithermal deposits. 
porphyry copper deposits from USA reported by Roedder (1984) based on their KCI-NaCl- $\mathrm{H}_{2} \mathrm{O}$ phases. According to Roedder, the $\mathrm{KCl}$ content of the fluids in the deposits of Bingham, Naica, and Red Mount is high and has increased to as high as the $\mathrm{NaCl}$ contents in some cases. On the contrary, the $\mathrm{NaCl}$ content is much higher than the $\mathrm{KCl}$ content in the deposits of Panguna, Granisle Bell, Tintic, Endaco, and Rio Pisco [19]. The Masjed Daghi fluid characteristics match the latter. The space-filling degree of multi-phase inclusions of Masjed Daghi is about $15 \%$ to $30 \%$. This together with the presence of lots of halite and sylvite in the samples imply the dominance of $\mathrm{H}_{2} \mathrm{O}-\mathrm{NaCl}$ and $\mathrm{H}_{2} \mathrm{O}-\mathrm{NaCl}-\mathrm{KCI}$ systems.

\subsection{Evidence of Boiling in the Masjed Daghi Mineralizing Fluids}

The occurrence of boiling and the temperature and pressure through which the boiling has happened can have a very important impact on the study of mineralizations. The boiling of mineralizing fluids is one of the most important factors in precipitation of mineralization in ore deposits [20]. The evidence of the occurrence of boiling of mineralizing fluids in Masjed Daghi include: 1) presence of single-phase gas inclusions (in samples like BH66-466, BH49-605, and BH39$1011), 2)$ presence of single-phase liquid inclusions as well as liquid-rich twoand multi-phase inclusions [15] [20] (sample BH49-605), 3) large gas bubbles in samples of BH49-605 and BH49-801, (4) two-phase liquid and gas inclusions filling $85 \%$ to $95 \%$ of samples BH49-801 and BH66-466 homogenizing to gas phase. Based on the Raman laser spectroscopic investigations, only one sample (BH39-383) contained $\mathrm{CO}_{2}$ [20]. Nevertheless, the lack of gases like $\mathrm{CH}_{4}, \mathrm{~N}_{2}, \mathrm{H}_{2}$, Ar, $\mathrm{H}_{2} \mathrm{~S}$, and $\mathrm{CO}_{2}$ in the majority of inclusions of Masjed Daghi may imply the release of such gases when boiling has occurred [20]. The diagram showing the homogenization temperature against halite dissolution temperature [15] was applied for halite-bearing multi-phase inclusions of samples BH49-605, BH52- 817, BH49-801, and BH66-466. This indicated that the Masjed Daghi samples plot along the line in the middle which implies $\mathrm{Th}(\mathrm{L}-\mathrm{V})=\mathrm{Tm}$ and therefore the occurrence of boiling process [15]. On the other hand, the presence of two groups of low temperature and low salinity inclusions (with average homogenization temperature of $186^{\circ} \mathrm{C}$ and average salinity of $6.23 \mathrm{wt} \% \mathrm{NaCl}$ equivalent) and high salinity and temperature (average homogenization temperature of $343^{\circ} \mathrm{C}$ and average salinity of $55 \mathrm{wt} \% \mathrm{NaCl}$ equivalent), low difference between the homogenization temperature and trapping temperature of fluid inclusions $\left(26^{\circ} \mathrm{C}\right.$ ), and the attribution of the greatest size of inclusions (18 micrometer) to two-phase liquid and gas inclusions (sample BH39-199) would also indicate the occurrence of boiling.

\subsection{The Thermometric Data of Fluid Inclusions}

One of the useful methods to summarize and display the fluid inclusion data including salinity, density, depth, pressure, homogenization temperature, halite dissolution, melting point, and freezing point is using column histograms based 
on the variables. The histograms of final homogenization temperature-frequency for 100 fluid inclusions indicate two major temperature ranges of $155^{\circ} \mathrm{C}$ and $515^{\circ} \mathrm{C}$ for mineralization. The histogram of halite dissolution temperature against frequency indicates that the temperature of $505^{\circ} \mathrm{C}$ has the highest frequency. The salinity histogram shows two individual mineralization phases based on salinity range (wt $\% \mathrm{NaCl}$ equivalent); one from $2 \%$ to $10 \%$ and the other from $30 \%$ and $66 \%$. The salinity of fluid inclusions is a useful guide to localize the main core of mineralization. In many types of ore deposits, the salinity of mineralizing fluids is greater at the primary stages of mineralization and as the mineralization proceeds, the salinity of the fluids would be reduced. Therefore, the inclusions with highest salinity degrees normally concentrate in the main body of the mineralization. Therefore, the presence of inclusions with high temperature and salinity in potassic zones can be correlated with the core of porphyry mineralizations. The most frequent ice melting temperature for $53 \mathrm{~L}+$ $\mathrm{V}$ inclusions from phyllic and potassic zones of Masjed Daghi is $-4^{\circ} \mathrm{C}$ which corresponds with $6.5 \mathrm{wt} \% \mathrm{NaCl}$ equivalent. Based on the histograms, the salinity of two-phase $(\mathrm{L}+\mathrm{V})$ inclusions of the final stages of mineralization has been very low compared to multi-phase inclusions. The histogram showing the distribution of homogenization temperature against dissolution temperature of salt in fluid inclusions indicate that most of the salt dissolution and homogenization temperatures have occurred from $350^{\circ} \mathrm{C}$ to $550^{\circ} \mathrm{C}$, and from $110^{\circ} \mathrm{C}$ to $550^{\circ} \mathrm{C}$, respectively. The fluid inclusions with high homogenization and salts dissolution temperatures correspond to the potassic zone of mineralization. The $\mathrm{L}+\mathrm{V}$ inclusions with homogenization temperature lower than $290^{\circ} \mathrm{C}$ compose the largest fluid inclusions of Masjed Daghi. The salinity and the salt dissolution temperature generally show a linear trend, although the sylvite-bearing inclusions do not follow this linear trend and show higher temperatures at the same salinity range.

\subsection{Homogenization of Fluid Inclusions Based on Salt Contents}

The fluid inclusions of the samples taken from Masjed Daghi were homogenized to gas and liquid phases, based on salinity percentage (without halite and undersaturated and saturated with halite). In the following the major outcomes of the studies on fluid inclusions of Masjed Daghi based on their salt content have been summarized:

- The liquid and gas inclusions lacking halite (e.g. samples BH49-605-12 and BH49-801-3) were homogenized to gas.

- The liquid and gas fluid inclusions undersaturated with halite (with a salinity of less than \%10 like samples BH45-831 and BH49-605a) were homogenized to liquid. Most of the undersaturated inclusions were of this type.

- The inclusions saturated with halite that were homogenized to liquid and gas phases can be divided into three groups:

- 3-a-Halite dissolution has occurred after the dissolution of gas phase and the 
final homogenization has occurred with halite dissolution. Samples BH49605, BH66-466, BH39-1011, BH-49-801, BH52-817, and BH38-441 were of this type and were located on the both sides of the halite saturation curve.

- 3-b-The dissolution of halite happened before gas phase dissolution and the final homogenization happened when there was gas phase dissolution, like the samples of $\mathrm{BH} 49-605$ and $\mathrm{BH} 52-817$ that were located in the upper part of the halite saturation curve.

- 3-c-The dissolution of halite happened concurrently with other phases and the final homogenization occurred as all phases were dissolved, like samples BH66-466, BH49-605, BH52-817, and BH49-801 that were located at the top of the halite saturation curve and formed the least number of samples saturated with halite.

\subsection{Evidence for Porphyry Mineralization in Masjed Daghi}

- Multi-phase fluid inclusions of $\mathrm{L}+\mathrm{V}+\mathrm{S}$ in Masjed Daghi have homogenization temperatures from $122^{\circ} \mathrm{C}$ to $550^{\circ} \mathrm{C}$ and salinities between 30.44 and 66.9 $w t \% \mathrm{NaCl}$ equivalent with an average of 55 . The maximum homogenization temperature of this group is $700^{\circ} \mathrm{C}$, while the maximum salinity is $84.5 \mathrm{wt} \%$ $\mathrm{NaCl}$ equivalent.

- Based on the Wilkinson diagram [20], all abovementioned samples are situated in the range of porphyry mineralization type (Figure 4).

- Based on the Raman laser spectroscopy investigations, the major daughter minerals of the inclusions include halite, sylvite, hematite, magnetite, anhydrate, rutile, and sphalerite.

- There is boiling evidence in the Masjed Daghi deposit.

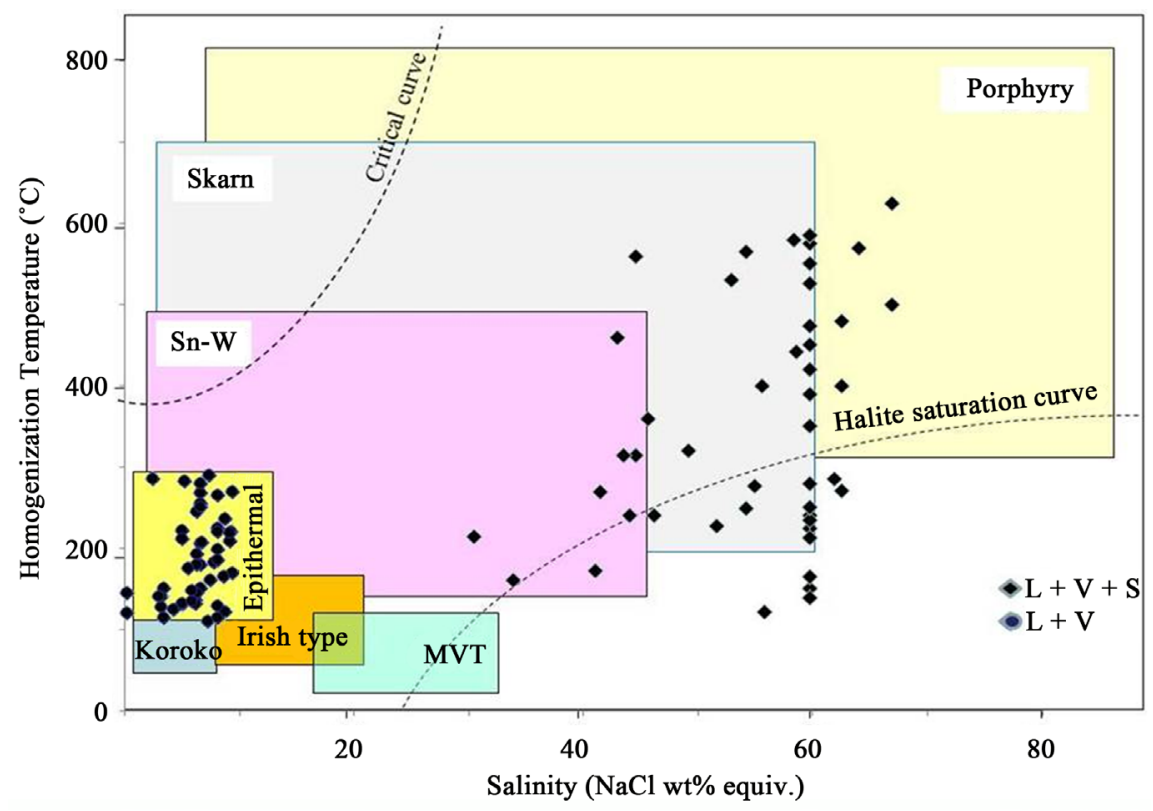

Figure 4. The Wilkinson (2001) diagram [20] showing the good match of fluid inclusions with both porphyry and epithermal mineralization types. 
- Fluid inclusions in Masjed Daghi area contain halite and sylvite and have an average salinity of $44.57 \mathrm{wt} \% \mathrm{NaCl}$ equivalent, while an average salinity of $31.13 \mathrm{wt} \% \mathrm{KCl}$ equivalent and regarding the phases of $\mathrm{KCI}-\mathrm{NaCl}-\mathrm{H}_{2} \mathrm{O}$, demonstrate a similar trend of porphyry copper deposits like Panguna, Granisle Bell, Tintic, Endaco, and Rio Pisco.

- Based on the petrographic investigations, diorite is the major intrusive rock hosting the mineralization in Masjed Daghi, while intrusive bodies of quartzmonzonite, monzodiorite, quartzdiorite and granodiorite can be found at depth and amphibole diorite on the surface outcrops. The texture of all intrusive rocks is porphyritic. The alteration is pervasive in the mineralization area and based on field and petrographic observations and XRD analysis include potassic, phyllic, argillic, silicfication and carbonatization.

- The vast stockwork zones together with irregular and thick silica veins can be clearly observed in the area. The function of faults and fractures has been crucial to the setting of veins and dikes in the area.

- Chalcopyrite, molybdenite, bornite, Chalcocite, covellite, sphalerite, tennantite, galena, magnetite, hematite, arsenopyrite, tetrahedrate, and pyrite are the most common minerals observed in polished-thin sections from the samples taken from the boreholes.

- Dissemination is the most common form of mineralization, nevertheless, the open space fillings, especially in the form of veins and veinlets are present as well

\subsection{Evidence for Epithermal Mineralization in Masjed Daghi}

- The two-phase fluid inclusions of $\mathrm{L}+\mathrm{V}$ have had homogenization temperatures from $110^{\circ} \mathrm{C}$ to $289^{\circ} \mathrm{C}$ and salinities from 0.21 to $9.9 \mathrm{wt} \% \mathrm{NaCl}$ equivalent. The average homogenization temperature of this group was $186^{\circ} \mathrm{C}$, while the average salinity was $6.23 \mathrm{wt} \% \mathrm{NaCl}$ equivalent (Figure 4).

- In the sample BH52-414, L + V inclusions were observed in quartz, sphalerite, and calcite which are characteristic of epithermal mineralization.

- According to the Raman laser spectroscopic investigations, only in one case $\mathrm{CO}_{2}$ gas was recognized. Lack of gases like $\mathrm{CO}_{2}, \mathrm{CH}_{4}, \mathrm{~N}_{2}, \mathrm{H}_{2}, \mathrm{Ar}$, and $\mathrm{H}_{2} \mathrm{~S}$ indicates the loss and release of such gases during boiling, which is one of the typical characteristics of epithermal mineralizations.

- Open space filling, dissemination, and vein and veinlets, are the most common textures observed in the samples.

- The sulfosalt minerals of tetrahedrate and tennantite which were abundantly observed in the samples are another characteristic of epithermal mineralization.

- Alteration is widespread in the area and includes potassic, phyllic, argillic, silicification, alunite, and carbonatization.

- The intrusion of plutonic bodies together with presence of volcanic rocks like andesite, trachyandesite, hornblende basalt, and dacite have provided the conditions required for circulation of mineralizing fluids. The free flow of 
hydrothermal fluids with intermediate temperatures close to the surface have caused the occurrence of thick and long silica veins together with irregular veins of gypsum in the fractures of the rocks of the area.

\section{Conclusions}

The major intrusive rock hosting the mineralization in Masjed Daghi is diorite, while intrusive bodies of quartzmonzonite, monzodiorite, quartzdiorite and granodiorite can be found at depth and amphibole diorite on the surface outcrops. The texture of all intrusive rocks is porphyritic. Dissemination is the most common form of mineralization, nevertheless, the open space fillings, especially in the form of veins and veinlets are present as well. The alteration is pervasive in the mineralization area and based on field and petrographic observations and $\mathrm{XRD}$ analysis includes potassic, phyllic, argillic, silicification, and carbonatization. Potassic and phyllic alterations were observed from near surface to the depth of $1011 \mathrm{~m}$.

In addition to thick silica veins and siliceous stockwork zones, the veins in mineralized area include mineralized grey silica veins, sulfide, silica-barite, white silica, gypsum, and calcite veins in order of their date of occurrence. Grey silica veins are the most abundant and the most ancient veins, while white silica veins are the youngest and calcite veins are the rarest veins. Some of samples contain both grey silica and younger white silicate veins. The white silica veins are observed in both parallel and intersecting forms to the grey silica veins.

The fluid inclusion studies on the abovementioned silica veins in Masjed Daghi area demonstrate the presence of two mineralizing fluids, one with high temperature and salinity (multi-phase $\mathrm{L}+\mathrm{V}+\mathrm{Ha}+\mathrm{S}$ with average homogenization temperature of $343^{\circ} \mathrm{C}$ and the average salinity of $55 \mathrm{wt} \% \mathrm{NaCl}$ equivalent), while the other fluid indicates a low temperature and salinity (two-phase $\mathrm{L}+\mathrm{V}$ with average homogenization temperature of $186^{\circ} \mathrm{C}$ and the average salinity of $6.23 \mathrm{wt} \% \mathrm{NaCl}$ equivalent). All the low temperature-salinity samples are in a good agreement with an epithermal mineralization type, while the high temperature-salinity samples are in a good agreement with a porphyry type of mineralization.

Based on the geothermometric studies, the grey silica veins with multi-phase inclusions (3-phase, 4-phase, and 5-phase) all showed the characteristics of porphyry mineralization type, while the white silica veins and silica-barite veins with single-phase liquid or gas or two-phase liquid and gas inclusions represented the characteristics of epithermal mineralization type. Fluid inclusions with the characteristics of porphyry mineralization can be observed in all samples (except borehole 45) up to the depth of $1011 \mathrm{~m}$. Fluid inclusions with epithermal characteristics are observed in the eastern part of the ore deposit up to the depth of $414 \mathrm{~m}$ and in northeast part up to the depth of $605 \mathrm{~m}$. The depth of the epithermal mineralization reaches up to $831 \mathrm{~m}$ (in the western part of the area). 
In the northern part of the ore body, the characteristics of the fluid inclusions (e.g. homogenization temperature, salinity, number of phases, etc.) are more diverse than the southern part. As the depth increases, the maximum size, the number of two-phase fluid inclusions, the dissolution temperature of halite, and the ice-melt temperature of fluid inclusions would reduce regularly, while the number of multi-phase inclusions, homogenization temperature, and the salinity and density of fluid inclusions increased orderly. The mineralizing fluids in northern part of the deposit have functioned more strongly-especially with the depth increase-compared to the southern part.

All the multi-phase and the sylvite-hematite-bearing inclusions were observed in the potassic alteration zone whose homogenization temperature and salinity reach up to $700^{\circ} \mathrm{C}$ and $84.56 \mathrm{wt} \% \mathrm{NaCl}$ equivalent, respectively. These high homogenization temperature and salinity might indicate the location of the core of the porphyry mineralization of the deposit.

Based on the diagram presented by Large (1988), most of multi-phase inclusions of Masjed Daghi are situated in the range of porphyry copper-gold chloride ligands and only a few multi-phase inclusions together with the entire twophase inclusions are plotted within the sulfide complex ligand area. The ratio of wt $\% \mathrm{NaCl} / \mathrm{KCI}$ equivalent of the fluid inclusions of Masjed Daghi is comparable with porphyry type deposits of Panguna, Granisle Bell, Tintic, Endaco, and Rio Pisco.

The pressure of trapping of the fluids has been 1150 bars and the depth of mineralization has been 4.34 kilometers. Based on the fluid inclusion studies, the boiling has occurred during mineralization in Masjed Daghi and the major mineralization has occurred in the temperatures of $155^{\circ} \mathrm{C}$ and $515^{\circ} \mathrm{C}$.

\section{Acknowledgements}

The present research was financially supported by the Research \& Development Department of National Iranian Copper Industries Company (NICICO). Hereby, the authors would like to appreciate the support and assistance of the management and the staff of NICICO, with special thanks to Mr. Afsar Eslami, Mr. Ali Norouzi Behjat, Mr. Majid Khosrojerdi, and Mr. Reza Esfahanipour.

\section{References}

[1] Geological Survey of Iran (2000) 1:5000 Geologic Map of Masjed Daghi Exploration Area.

[2] National Iranian Copper Industries Co. (2009) Report of Geology Investigations and Exploration Operations in Masjed Daghi Area. Internal Report in Persian, 189.

[3] Akbarpour, A. (2005) Economic Geology of Kiamaki Area Regarding Gold and Copper Mineralization (Masjed Daghi Jolfa) in Eastern Azerbaijan. Unpublished PhD Dissertation (in Persian), Science and Research Branch, Islamic Azad University, Tehran, 262.

[4] Zonouzi, R. (2006) Study of Mineralization and Recognition of Gold Ore Deposit Genes in the Masjed Daghi Area (Southeast of Jolfa). Unpublished MSc Thesis (in 
Persian), Science and Research Branch, Islamic Azad University, Tehran, 137.

[5] Yadollahi-e-Meidani, R. (2010) Study of Fluid Inclusion and Stable Isotopes (O, H, C, S) in Masjed Daqhi Ore Deposit, Jolfa, Eastern Azarbaijan, Iran. Unpublished MSc Thesis (in Persian), University of Tehran, 141.

[6] Ebrahimi, S. and Alirezaei, S. (2010) Genetic Relationship between the Epithermal Gold and Porphyry Copper Mineralizations in the Masjed Daghi Deposit, NW Iran. 29 th Iranian Conference of Geosciences, Geological Survey of Iran, Tehran.

[7] Aghazadeh, M., Hou, Z., badrzadeh, Z. and Zhoux, L. (2015) Temporal-Spatial Distribution and Tectonic Setting of Porphyry Copper Deposits in Iran: Constraints from Zircon U-Pb and Molybdenite Re-Os Geochronology. Ore Geology Reviews, 70, 385-406.

[8] Nabavi, H. (1976) An Introduction to Geology in Iran. Geological Survey of Iran, 56.

[9] Aghazadeh, M., Castro, A., Badrzadeh, Z. and Vogt, K. (2011) Post-Collisional Polycyclicplutonism from the Zagros Hinterland: The Shaivar Dagh Plutonic Complex, Alborzbelt, Iran. Geological Magazine, 148, 980-1008.

https://doi.org/10.1017/S0016756811000380

[10] Jamali, H. (2012) Metallogenic Zonation and Their Tectono-Magmatic Control at Ahar-Arasbaran Magmatic Belt, NW Iran, Unpublished PhD Dissertation (in Persian), Kharazmi University, Tehran, 354.

[11] Atalou, S. (2009) Study of the Distribution and Priority of Exploration of Metallic Occurrences in Northwest of Iran. National Iranian Copper Industries Company (Internal Report in Persian), 120.

[12] Hass, J.L. (1971) The Effect of Salinity on the Maximum Thermal Gradient of a Hydrothermal System at Hydrostatic Pressure. Economic Geology, 66, 940-946. https://doi.org/10.2113/gsecongeo.66.6.940

[13] Gunter, W.D., Chon, I.-M. and Girsperger, S. (1983) Phase Relations in the System $\mathrm{NaCl}-\mathrm{KCl}-\mathrm{H}_{2} \mathrm{O}$ II: Differential Thermal Analysis of the Haliteliquids in the $\mathrm{NaCl}-$ $\mathrm{H}_{2} \mathrm{O}$ Binary above 450 8C. Geochimica et Cosmochimica Acta, 47, 863-873.

[14] Brown, P.E. (1989) FLINCOR: A Microcomputer Program for the Reduction and Investigation of Fluid Inclusion Data. American Mineralogist, 74, 1390-1393.

[15] Shepherd, T.J., Rankin, A.H. and Alderton, D.H. (1985) A Practical Guide to Fluid Inclusion Studies. Blackie and Sons, 239.

[16] Bodnar, R.J. and Vityk, M.O. (1994) Interpretation of Microthermometric Data for $\mathrm{H}_{2} \mathrm{O}-\mathrm{NaCl}$ Fluid Inclusions. In: De Vivo, B. and Frezzotti, M.L., Eds., Fluid Inclusions in Minerals. Methods and Applications, IMA Short Course Volume, Virginia Polytechnic Institute and State University Press, 117-130.

[17] Hajalilou, B. (2008) Geo-Thermometry of Fluid Inclusions. Payam-e-Nour Publications, 309. (In Persian)

[18] Large, R., Huston, D., Mc Goldbrick, P. and Mc Arture (1988) Gold Distribution and Genesis in Paleozoic Volcanic Massive Sulphide System. Geological Society of Australia, 22, 121-128.

[19] Roedder, E. (1984) Fluid Inclusions, Reviews in Mineralogy. Vol. 12, Mineralogical Society of American, 646.

[20] Frezzotti, M.L., Tecce, F. and Casagli, A. (2012) Raman Spectroscopy for Fluid Inclusion Analysis. Journal of Geochemical Exploration, 112, 1-20. 
Submit or recommend next manuscript to SCIRP and we will provide best service for you:

Accepting pre-submission inquiries through Email, Facebook, LinkedIn, Twitter, etc. A wide selection of journals (inclusive of 9 subjects, more than 200 journals)

Providing 24-hour high-quality service

User-friendly online submission system

Fair and swift peer-review system

Efficient typesetting and proofreading procedure

Display of the result of downloads and visits, as well as the number of cited articles Maximum dissemination of your research work

Submit your manuscript at: http://papersubmission.scirp.org/

Or contact ojg@scirp.org 